\begin{tabular}{c} 
Volume and Issues Obtainable at Center for Sustainability Research and Consultancy \\
Review of Politics and Public Policy in Emerging Economies \\
ISSN: $2708-3829 \&($ E):2708-356X \\
Volume 3: No. 1, June 2021 \\
CSRC \\
Journal homepage: www.publishing.globalcsrc.org/rope \\
\hline
\end{tabular}

\title{
Role of Political Instability in Attracting FDI Inflow to Pakistan
}

Dil Jan, Department of Economics Islamia College Peshawar, Pakistan *Muhammad Sibt-e-Ali, PhD Scholar, School of Business, Zhengzhou University, Henan, China Muhammad Taqi, School of Economics, Bahauddin Zakaryia University, Multan, Pakistan Sabiha Parveen, The Women University Multan, Pakistan

*Corresponding author's email: ali4bzu @ gmail.com

\begin{tabular}{l}
\hline ARTICLEDETAILS \\
\hline History \\
Revised format: May 2021 \\
Available Online: Jun 2021
\end{tabular}

Keywords

FDI, Interest rate, Polity, ARDL Approach, Pakistan

JEL Classification
B21, B22, B40, C01

\section{OPEN ACCESS}

\begin{abstract}
Purpose: The purpose of this study is to recognize the impact of key determinants of overseas direct asset in case of Pakistan, based on annual information covering the period of 1981-2018.

Design/Methodology/Approach: After checking for still of the sequence, the technique of ARDL is used for estimation of long run parameters estimates and error alteration instrument for short run dynamics.
\end{abstract}

Findings: The results of the study indicate that politically stable environment and long term policies are necessary to attract foreign investors. furthermore, investment profile of any government also matter for direct asset in the country as the study conclusions reveal that marketplace size as well as domestic investment are positively related to foreign direct investment while taxes have negative association with overseas straight investment in the case of Pakistan.

Implications/Originality/Value: The most important factor for FDI inflow to Pakistan is interest rate or ease of doing business which has negative sign means inverse relation exists between the two variables.

(C2021The authors, under a Creative Commons AttributionNonCommercial 4.0

\footnotetext{
Recommended citation: Jan, D., Ali, M. S., Taqi, M. and Parveen, S. (2021). Role of Political Instability in Attracting FDI Inflow to Pakistan. Review of Politics and Public Policyin Emerging Economies, 3(1) 41-49.
}

\section{Introduction}

Developing countries are facing a lot of financial problems, but the main problem is that they have the lack of national savings to improve their investment. To expand their investment they need stability in foreign capital, but this strategy would be only applicable in open economy. The inadequacy of domestic saving, the foreign capital flow is used to finance the domestic investment in open economy. Flow of capital contains foreign direct investment as well as indirect investment. Foreign direct speculation is different from straight speculation like as portfolio flows while the indirect investment refers to that investment which mentioned in the list 
of stock exchange in the form of equities, bounds and shares etc. The Classical School of thoughts defined foreign direct investment as, physical investment of one state build the factory in to another state. Agiomirgianakis et al. (2003) defined foreign direct investment as; the performance of international companies due to the capital flow. Therefore, the features which affect the performance of multinational companies might affect the direction and magnitude of foreign direct investment. Whenever the trade openness increased it will increased the economic growth because the country will able to create such environment which attract the foreigner investor (Surge et al. 2008). While in case of Nigeria, trade openness and market size do not affect the FDI in long run but in little run inflation positively affect Foreign Direct Investment (Abubakar, 2013).

The importance of flows of foreign direct investment of rising countries is captured in many literatures. In rising nations the inflows of Foreign Direct Investment was recorded almost zero during the period of pre-liberalization. Conversely, strong Foreign Direct Investments are evidenced in the era of post liberalization. FDI is depend on the many factors which included Population growth, Inflation rate, the volume of export and the tariff impose on export (Khan, \& Nawaz, 2010). Trade openness, labor force participation, and monetary enlargement have an optimistic impact on FDI, even as the political stability and exchange rate have a unenthusiastic impact on FDI (Rabbia, 2010). Terrorism, inflation rate, and exchange rate of a country have a pessimistic influence on FDI (Afza, \& Anwar, 2014).

During the period of 1980's the restraints on foreign direct investment reduced by several countries and most of the countries provide subsidies for the attraction on foreign capital (Aitken \& Harrison, 1999). Taxes and location of the business have negative impact on FDI (Gastanaja, et al. 1998). The low cost of production (the taxation policy) in the home country are an incentive for the foreigner firms. The price factor consists of the capital relative wage rate, transport expenses, as well as the economic incentive in form of tax by the host state (Root and Ahmed, 1979). Some studies suggested that Labor force participation plays a very important role in FDI in developing countries. According to Hussain, \& Kimuli, (2012) increase in labor force will cause to increase FDI. The major sources of the attraction of FDI are educated peoples and sophisticated labor force (Ismail, \& Yussof, 2003). FDI has an optimistically association by means of Population increase, rate of Exchange, Economic growth and inflation. If a country fetch the stability in there exchange rate than obviously they will attract the foreign investor (Rashid, M. et al. 2013). According to Azam, \& Lukman, (2010) Foreign investors are encourages for the domestic investor to create a political and economic stability environment. Along with these policy changes, a surge of noncommercial bank private capital flow to developing economies occurred in 1990s. Meyer (2003) stated that foreign direct investments have full-grown at slightest double as quickly as buy and sell throughout 1990s. Similarly the effect of trade rate actions on FDI flow is rather fine reached subject, while the magnitude and direction of pressure is far beginning sure. According to Froot and Stein (1991) that the decrease of the crowd money should add to FDI into the congregation country, and on the contrary an increase in the value host money should decline FDI. While the study of Edal and Tatogu (2002) establish so as to exchange rate has negative impact on FDI. The approval of exchange rate has a negative impact on FDI, because it influences the price of assets in that country (Love and LageHidalgo, 2000). According to the study of Shah and Ahmed (2003), that FDI is positively relative with GDP, GNP and export in Pakistan. Whenever FDI increase then it will direct affects the investment outflows, while negative impact on current account in case of Pakistan (Jaffri, et al 2011). Foreign direct investment has positive impact on Dictatorship, financial enlargement and trade openness (Minhas \& Ihsan, 2015).

The major plan of the present study is to investigate for the key features responsible for the low inflows of FDI to Pakistan sine last few decades. This present study will contribute to the 
literature as it uses new methodology for empirical investigation of the time trend. In case of Pakistan no research study has used Engel and Granger approach to inspect the key factors hindering in the way of FDI inflow to the state, so this study will make donation in the sense as it uses new methodology to confirm the connection among the financial variables. This study supposes that FDI is significantly predisposed by the gross domestic product (proxy for market size), domestic investment, taxes, Political instability, as well as price rises rate as well as interest rate. Based on previous literatures, this study uses FDI as response variable, and the market size or output level, domestic investment, inflation and taxis as independent variables. Through this study we will try to answer the question that, is following instability matter for foreign invest in any economy like Pakistan.

\section{Material and Methods}

This revision is due to time sequence secondary data converting the era of 1981to 2018. The statistics for all variables has been collected form Handbook of statistic a magazine of the state Bank of Pakistan except Polity which is taken from World Governance Indicators (WGI). Based on the previous literature this study concluded that different research studies investigated different variables to find the influence of them on the FDI inflow to Pakistan, but the consequences ambiguous. Moreover, previous studies used dummy variable to inspect the influence of political instability on FDI, in case of Pakistan political instability index is used in some research studies, but their results are inconclusive. The study by Minhas, A., and Ahsan, A., (2015) Rehman, et. al.(2008) \& Azam, \& Lukman, (2010)obtained contradictory results. So in the light of the on top of mention studies this study an effort to answer the question that how supporting unsteadiness as well as other social and economic factors effect FDI inflows to Pakistan. This study will utilize the following model.

$$
\ln F D I=\alpha+\beta_{1} G D P+\beta_{2} \ln R+\beta_{3} \ln I N V+\beta_{4} \ln T A X+\beta_{5} \text { polity }+\mu_{t}
$$

Where,

$$
\begin{aligned}
& \text { In = natural logarithm } \\
& F D I=\text { Foreign Direct Investment, } \\
& G D P=\text { Gross Domestic Product (market size) } \\
& \text { INV = D .Investment } \\
& R=\text { Prevailing interest rate in the economy } \\
& T A X=\text { Taxes } \\
& \text { Polity = Political instability index (A proxy for regime) } \\
& \mu \quad=\text { white noise error term } \\
& t \quad=\text { for time period }
\end{aligned}
$$

We anticipate that the coefficient of GDP and investment would be helpful. The coefficient for taxes Political instability and interest rate would be negative.

\section{Unit Root Test}

Past literature also suggests us some other test to check stationary in data. The present study consists of five variables and used Augmented Dickey Fuller (ADF) test to make sure the unit root in information. According to Gujarati (2007) ADF test is frequently uses for time series data. The specification and hypothesis of unit root are given below:

$$
\Delta y_{t}=\beta_{0}+\beta_{1} t+\gamma y_{t-1}+\alpha i \sum_{i=1}^{p} \Delta y_{t-i}+\mu_{t}
$$

The testing of hypothesis depends upon the coefficient value of dependent variable. In the above equation $\gamma$ represents coefficient value of dependent variable. The alternative and null hypotheses 
of the test are given below:
Null hypothesis:
$\gamma=0$
(unit root)
Alternative hypothesis:
$\gamma \# 0$,
(no unit root)

The null hypothesis will be discarded and the substitute supposition will be conventional if the coefficient value is greater than zero. When we accept the alternative hypothesis then it means that the sequence of data is still at level. Similarly, the acceptance of null hypothesis at level then it means that the variables are integrated at first order or in simple words the data is non stationary at level.

\section{Co-integration Approach}

As then unit root analysis, we can carry on with Co-integration tests. We are paying attention in the extended run connection between FDI and its major determinants. Co-integration analysis is an appropriate method. For the purpose, we employ the Engle and Granger (1987) estimation technique. Engle and Granger (1987) suggest three steps for test of Co-integration. First, confirm that the every variable in representation is of the same order. Second, if the variables are of the same order, we should have to regress FDI in present case on constant and explanatory variables by ordinary least square (OLS). Third, test that the residuals from regression in stage-2 are of integrated zero order i.e. I (0) by using the greater than before dickey fuller examination. If the residuals are stationary at level, this linear combination can be understood as a long run equilibrium association.

\section{Results and Discussion \\ Unit Root Results}

The unit root is tested for variables under consideration. Before judgment of co-integration it is significant to check the stationary among variables. For this purpose ADF test is used to make sure stationary in time series data (to make sure whether the variables are motionless or nonstationary). The null hypothesis of the test is supposing to unit root in the sequence while the option hypothesis resume to no unit root. If the null hypothesis is rejects then it means that the variables are stationary. Table 2 shows the consequences of ADF test at first difference as well as at level

Table 6.1: $\quad$ ADF Test Results

\begin{tabular}{|l|l|l|l|l|}
\hline \multicolumn{2}{|l|}{} & \multicolumn{2}{l|}{ At level } & \multicolumn{2}{l|}{ At first difference } \\
\hline Variable (in log) & test-statistic & $p$-values & test-statistic & $p$-values \\
\hline FDI & -2.79 & 0.2103 & $-5.76^{*}$ & 0.0003 \\
\hline GDP & -2.31 & 0.4157 & $-3.98^{* *}$ & 0.0202 \\
\hline INV & -2.72 & 0.2329 & $-3.24^{* * *}$ & 0.0948 \\
\hline TAX & -2.19 & 0.4753 & $-3.92^{* *}$ & 0.0235 \\
\hline $\mathrm{R}^{\#}$ & -2.21 & 0.4652 & $-3.25^{* *}$ & 0.0264 \\
\hline Polity & -1.32 & 0.3256 & $-2.65^{* *}$ & 0.0410 \\
\hline
\end{tabular}

Note: The $*, * *, \& * * *$ represents the level of significance at 1 percent, 5 percent and 10 percent respectively. The series regression equation include for intercept and trend. @ If we exclude for the intercept and trend in regression then INV is significant at 1 percent after first difference. 
\#. The regression of $\mathrm{R}$ only includes for the intercept.

Table 1 represents the results of ADF test at the first difference and at level for the variables i.e. R, FDI, GDP, INV, and TAX. The results of ADF test stated that that all the variables are non stationary at level. On the other hand, it's become stationary at first difference at $1 \%, 5 \%$ and at $10 \%$. It is obvious from the above results that all variables are included at first order at level as well as integrated zero order at first dissimilarity. Therefore, literature suggested using of EngelGranger approach of co integration.

\section{Co-integration Results}

Person financial time sequence may not be stationary, but there may be belongings of linear mixture among them. This way that non-stationary financial time sequence may generate stationary relations if they are co integrated. As told earlier, for this we test unit root of regression residuals. If residuals exhibit no unit roots, the variables in model are said to be co integrated. Therefore, the specified regression equation (1) is predictable using normal OLS. The consequences are reported in Table 6.2.

Looking at the results in Table 6.2, it is obvious that in long run the output level and domestic investment affects foreign direct investment positively in Pakistan. The coefficient of GDP is important at 10 percent level of implication. The 1 percent change in output will guide to boost 2.87 percent foreign direct investment of the country. The coefficient of domestic investment is significant at 5 percent level of consequence as well as the coefficient value is 1.46 which is elastic. Contrary, the coefficient value of taxes is negative of value -0.32 and significant at 5 percent level of significance. The variable of interest polity which is negatively related which FDI. However, the effect of $\mathrm{R}$ is significantly negative. The value of $\mathrm{R}$-square is 0.98 which indicate that the representation explain 98 percent difference in FDI. The higher value of Fstatistic reveals that the model in overall is significant. The Durban-Watson test value is 1.75 which supports no autocorrelation in the model.

Table 6.2: $\quad$ The Long Run OLS Results

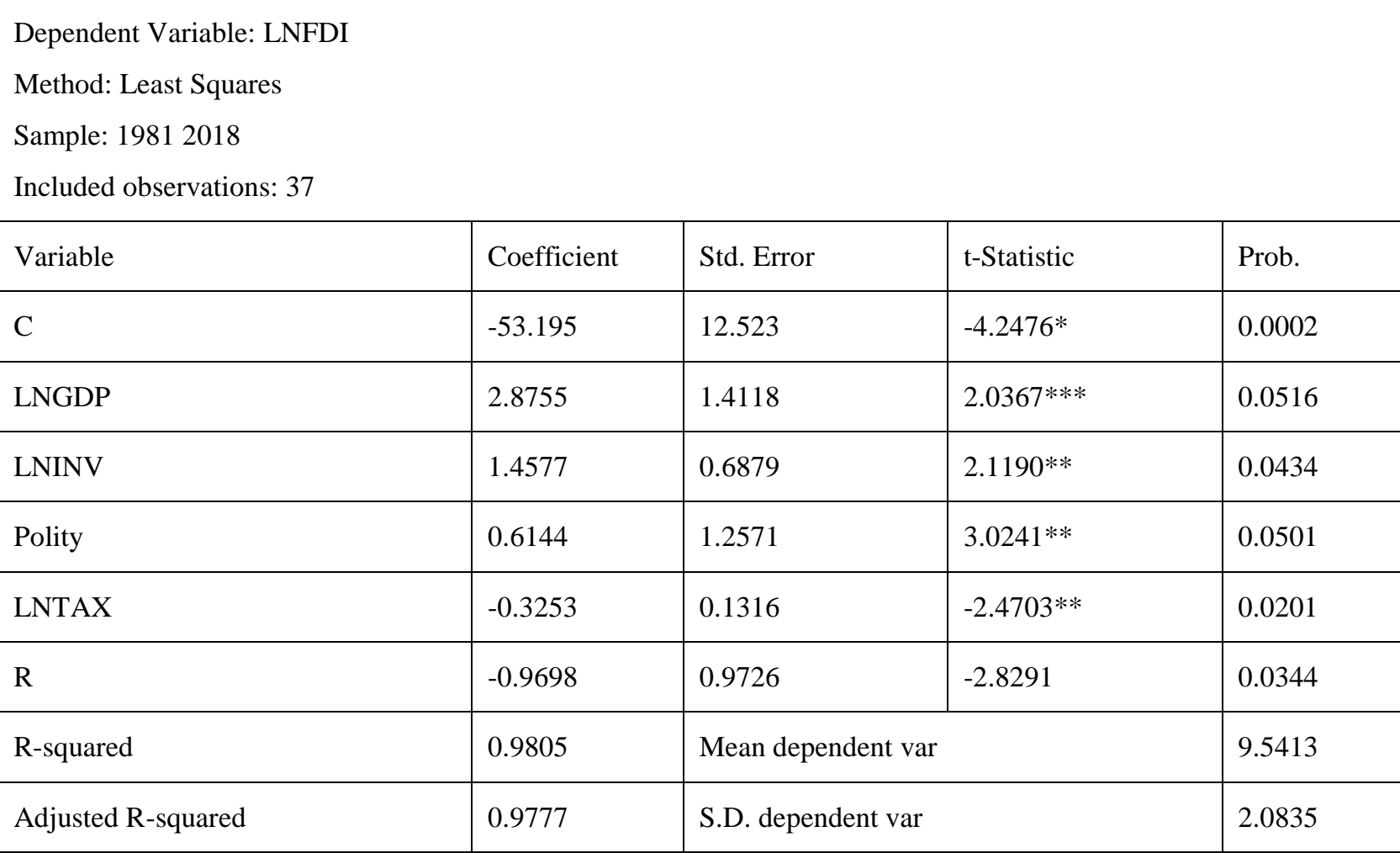




\begin{tabular}{|l|l|l|l|}
\hline S.E. of regression & 0.3110 & Akaike info criterion & 0.6447 \\
\hline Sum squared resid & 2.6119 & Schwarz criterion & 0.8737 \\
\hline Log likelihood & -5.3156 & Hannan-Quinn criter. & 0.7206 \\
\hline F-statistic & 341.04 & Durbin-Watson stat & 1.7527 \\
\hline Prob(F-statistic) & 0.0000 & & \\
\hline
\end{tabular}

Note: The $* * *$, and $* * *$ above t-statistic represent the 1 percent, 5 percent, as well as 10 percent level of importance correspondingly. Furthermore, if we include for the option of White Hetroscedasticity Standard Error and Covariances in estimation procedure the coefficients become highly significant. The long run results when allows for white's option are reported in Table A1 in appendix The above results can be considered long run, if the residuals from the regression do not exhibit unit root at level. Therefore, the ADF test is run on the residuals as well as the consequences are reported in Table 6.4.

Table 6.3: $\quad$ ADF Test Results on Residuals

Null Hypothesis: RESID02 has a unit root

Exogenous: Constant

Lag Length: 4 (Automatic based on SIC, MAXLAG=7)

\begin{tabular}{|l|l|l|l|}
\hline \multicolumn{2}{|l|}{ Augmented Dickey-Fuller test statistic } & t-Statistic & Prob.* \\
\cline { 3 - 4 } & & $\mathbf{- 4 . 4 6 5 8 3 2}$ & $\mathbf{0 . 0 0 1 6}$ \\
\hline \multirow{2}{*}{ Test critical values: } & $1 \%$ level & -3.699871 & --- \\
\cline { 2 - 4 } & \multirow{2}{*}{$5 \%$ level } & -2.976263 & - -- \\
\cline { 2 - 4 } & $10 \%$ level & -2.627420 & --- \\
\hline \multirow{2}{*}{$*$ MacKinnon (1996) one-sided p-values. } & & \\
\hline
\end{tabular}

Table 6.3, it is obvious that the t-Statistic is considerable at 1 percent level of significance. Engle and Granger (1987) suggest that the results will not specious if the residuals from integrated series are stationary at level. Further, states that the sequence are then said to be co-integrated. Thus, the residuals are stationary at level at 1 percent. Based on results, conclude that the residuals are stationary as well as confirm the long run relationship in model. The residuals are also plotted in figure for more visible look (see Figure A1 in Appendix)

\section{Error Correction Representation}

This section of analysis focuses on the results for short run elasticity estimates and error correction coefficient. The error correction model consequences are reported in Table 6.5 as given: 
Table 6.5: $\quad$ The Error Correction Model Results

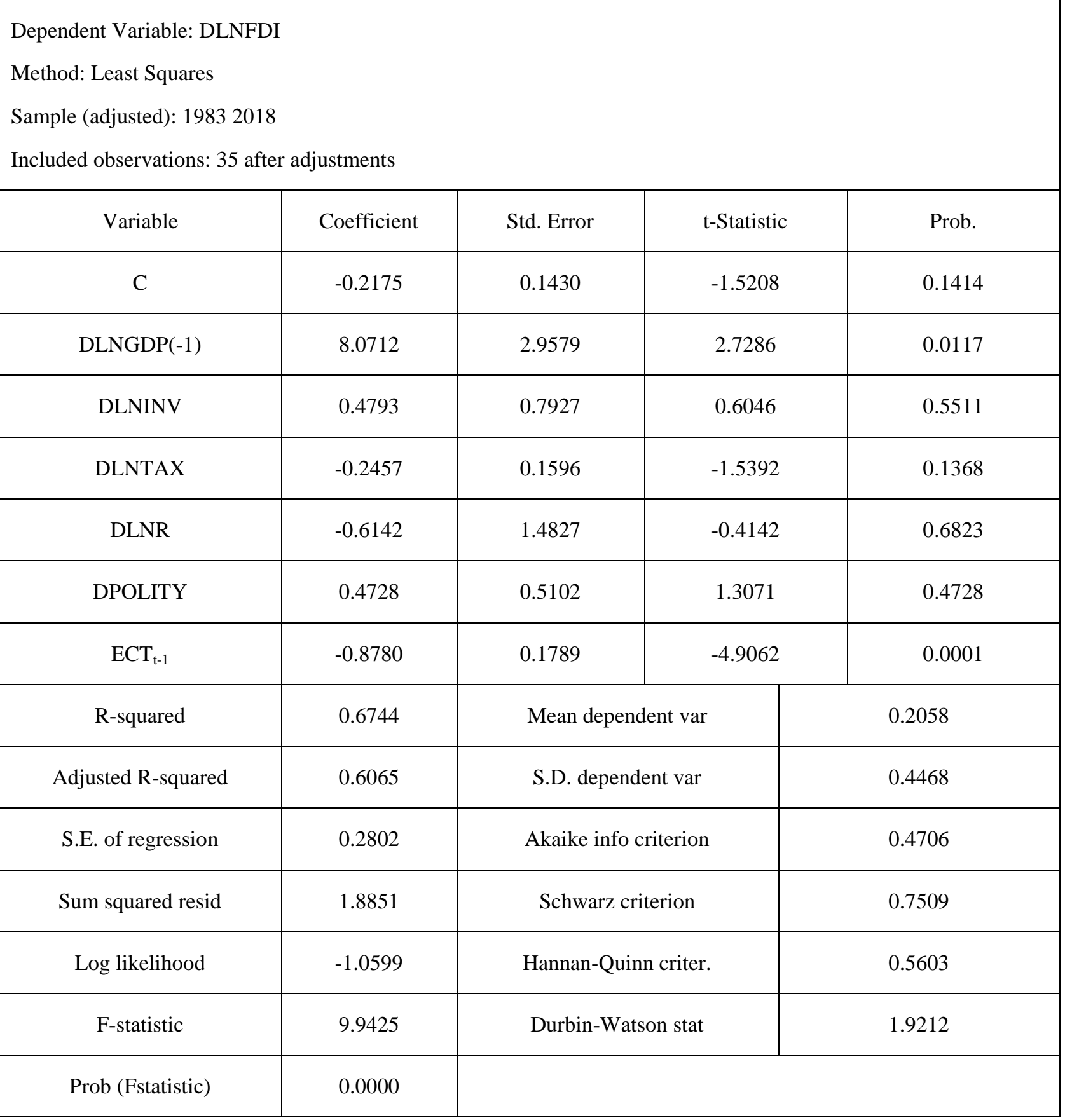

The difference variables coefficient represents the short run effects in the representation. The coefficient of error correction term (ECT) is used to measure for the speed of adjustment in the representation. It is obvious that the coefficient of lagged GDP is significant at 5 percent. The other variables are looking insignificant in the error correction model. However, the coefficient of residuals lagged value is significant at 1 percent and of value -0.88 . The negative value of ECT less than 1 also validates co-integration in the model. The error correction term coefficient indicates that the foreign direct investment after short run divergence return to its long run balance with speed of 88 percent per annum.

\section{Conclusion}

The most important factors of the modern globalized world are foreign direct investment (FDI). Any country of the world which has a large amount of FDI would consider in high economic growth and stable countries. The FDI in developing countries is useful in the contraction of gap 
between saving and investment. The decision taking against spreading out the business of multinational companies to other countries on the bases of little cost of productivity, high effectiveness, easily accessibility of raw material and the expectation about the market size. FDI also provide the economic benefit to countries like as; the new technologies and its related knowledge will move from highly industrial nations to other developing countries. It also increases the human capital in term of training of manpower etc. Mostly, Developing countries are trying to attract the foreign investors. Pakistan is also experiences of developing countries which taking the effective policies for FDI.

The present study investigated empirically the main determinants of foreign direct investment (FDI) in case of Pakistan. Annual time series data is utilized during the period of 1981 to 2018. For unit root ADF test is functional to test stationary in data. Co-integration techniques are used for the propose to estimate the long run affiliation between the variable of interest and also used Error correction (EC) techniques to analyzed the impact of independent variables on dependent variables. The long run consequence of the study shows that FDI has direct impact on output level and domestic investment. Tax model expressed resulted that taxes are negatively correlated and the Nominal interest rate is negatively associated with FDI. The results of the output level showed that one per cent increase in output level would cause to increase FDI by 2.8 per cent in long run. Similarly, one per cent increase in domestic investment would cause to increase FDI by 1.4 per cent. Positive sign of political instability index show positive association with FDI in Pakistan. it is due the fact that the country received a high percentage of inflow in the regime of dictatorship up to 3 percent of GDP, and afterward it begin to decline and dropped down to 0.31 percent. Furthermore, the historical background of FDI inflows to Pakistan also shows that during the regime of dictatorship more foreign investors take interest to invest in different sectors due to the surety of the government long term policies and the duration moreover, mostly dictators take interest to invite foreigner to invest rather to improve their own business. Due to all these facts the sign of political instability is positive. On the basis of the consequences of this study the subsequent advices are optional for the long-run financial profits of FDI in Pakistan:

- $\quad$ Policy makers should provide conducive and friendly environment to foreign investors to attract more FDI.

- The government of Pakistan should increase its output level and domestic investment to attract FDI.

- $\quad$ The government should decrease taxes and provide opportunities to foreign investors through ease of doing business.

- On the basis of the results of this study it is suggested that political workers must take interest to give opportunity to foreign investors in order to enhance economic growth and take the advantages of FDI.

\section{References}

Agiomirgianakis, G. M., Asteriou, D., \& Papathoma, K. (2003). The determinants of foreign direct investment: A panel data study for the OECD countries.

Anwar, Z., \& Afza, T. (2014). Impact of terrorism, gas shortage and political instability on FDI inflows in Pakistan. Science International, 26(1), 507-511.

Azam, M., \& Lukman, L. (2010). Determinants of Foreign Direct Investment in India, Indonesia and Pakistan: A Quantitative Approach. Journal of Managerial Sciences, 4(1).

Akbar, M., \& Akbar, A. (2015). An empirical analysis of foreign direct investment in Pakistan. Studies in Business and Economics, 10(1), 5-15.

Azam, M., \& Lukman, L. (2010). Determinants of Foreign Direct Investment in India, Indonesia 
and Pakistan: A Quantitative Approach. Journal of Managerial Sciences, 4(1).

Brown, R. L., Durbin, J., \& Evans, J. M. (1975). Techniques for testing the constancy of regression relationships over time. Journal of the Royal Statistical Society: Series B (Methodological), 37(2), 149-163.

Carkovic, M., \& Levine, R. (2005). Does foreign direct investment accelerate economic growth. Does foreign direct investment promote development, 195.

Froot, K. A., \& Stein, J. C. (1991). Exchange rates and foreign direct investment: an imperfect capital markets approach. The quarterly journal of economics, 106(4), 1191-1217.

Gujarati, D. N. (2007).“Basic Econometrics”, 4th edition, McGraw-Hill, Publishing Company Ltd.

Hussain, F., \& Kimuli, C. K. (2012). Determinants of foreign direct investment flows to developing countries. SBP Research Bulletin, 8(1), 13-31.

Ismail, R., \& Yussof, I. (2003). Labour market competitiveness and foreign direct investment: The case of Malaysia, Thailand and the Philippines. Papers in Regional Science, 82(3), 389-402.

Khan, R. E. A., \& Nawaz, M. A. (2010). Economic determinants of foreign direct investment in Pakistan. Journal of Economics, 1(2), 99-104.

Love, J. H., \& Lage-Hidalgo, F. (2000). Analysing the determinants of US direct investment in Mexico. Applied Economics, 32(10), 1259-1267.

Meyer, K. E. (2003). FDI spillovers in emerging markets: A literature review and new perspectives. Copenhagen Business School (Mimographed.), 2.

Najaf, R., \& Najaf, K. (2006). Impact of political stability on the macroeconomic variables and FDI of Pakistan. World, 2007(2008), 2009.

Root, F. R., \& Ahmed, A. A. (1979). Empirical determinants of manufacturing direct foreign investment in developing countries. Economic development and cultural change, 27(4), 751-767.

Shah, Z., Ahmed, Q. M., \& Siddiqui, R. (2003). The Determinants of Foreign Direct Investment in Pakistan: an Empirical Investigation [with Comments]. The Pakistan Development Review, 697-714.

Samimi, A. J., Moghaddasi, R., \& Azizi, K. (2011). Political stability and FDI in OIC countries. Journal of Social and Development Sciences, 1(1), 18-23.

State Bank of Pakistan, “A Handbook of Statistics, October 2010”, Karachi, Pakistan.

Siddiqui, D. A., \& Ahmad, M. H. (2012). The causal relationship between Foreign Direct Investment and Current Account: an empirical investigation for Pakistan economy. European Journal of Economics, Finance and Administrative Sciences ISSN, 1450-2275.

Tantratananuwat, P. (2015). Vertical and Horizontal FDI Technology Spillovers in Thai Manufacturing: Does Measurement Matter? (Doctoral dissertation, Doctoral dissertation, THAMMASAT UNIVERSITY).

Yousaf, M. M., Hussain, Z., \& AHMAD, N. (2008). Economic evaluation of foreign direct investment in Pakistan. Pakistan economic and social review, 37-56. 